\title{
STUDIES ON NEUROTOXICITY CAUSED BY STREPTOMYCIN AND ITS ANALOGUES
}

\author{
KEI NISHIDA*, SHOJI SAITO, KENJIRO OWADA, YUKIKO \\ TOKUNAGA, JYU KUDO, MASANORI MAEDA \\ and AKIRA KOINUMA \\ Department of Pharmacology, School of Medicine \\ Keio University
}

(Received on March 6, 1957)

\section{INTRODUCTION}

The disturbances of the eighth nerve due to streptomycin have been studied by many scholars in this country and else where. They are now paying special attention to the prevention of these disturbances. Molitor ${ }^{(1)}$ and Hawkins ${ }^{(2)}$ have already reported in detail the signs and the progressive changes caused by the long period of repeated injections of the drugs in various animals. However, before we investigated the prevention of the side effects of drugs, we experimented with the chronic neurotoxicity of streptomycin and its analogues in order to obtain more knowledge.

\section{EXPERIMENTS MADE AND METHODS}

We used cats weighing about $2 \mathrm{~kg}$ as experimental animals. The drugs which we used were streptomycin sulfate (Lot No. ss-71), dihydrostreptomycin sulfate (Lot No. ss-82, ss-89), distrycin, streptidine and guanidine. These drugs were used either intramuscularly or intracisternally in cats. All cats had the following preliminary tests daily prior to the injections of the drugs.

The hearing power was tested by Preyer's reflex and cochlear microphonic responses. The equilibrium was tested by the appearance of ataxia or the disappearance of rightening reflex and horizontal nystagmus (10 rotation/15 seconds). We used 40 cats, 20 cats received intracisternal injections without anaesthesia and 20 cats received intramuscular injections.

\section{EXPERIMENTAL RESULTS}

Streptomycin sulfate and its analogues were injected both intracisternally or intramuscularly in cats every day for a long period of time and we observed the appearance of various signs mentioned above.

\footnotetext{
* Professor of Pharmacology.
} 
16 K. Nishida, S. Saito, K. Owada, Y. Tokunaga, J. Kudo, M. Maeda, \& A. Koinuma

1) As illustrated in Table 1 , streptomycin $150 \mathrm{mg} / \mathrm{kg}, 200 \mathrm{mg} / \mathrm{kg}$ and $300 \mathrm{mg} / \mathrm{kg}$ were injected in the backmuscles of three cats every day for $87,44,29$ days respectively.

Table 1

Streptomycin sulfate Injected Intramuscularly

\begin{tabular}{|c|c|c|c|c|c|c|c|c|c|}
\hline \multirow[b]{2}{*}{$\begin{array}{l}\text { Cat } \\
\text { No. }\end{array}$} & \multirow{2}{*}{$\begin{array}{c}\text { Dose } \\
(\mathrm{mg} / \mathrm{kg})\end{array}$} & \multicolumn{2}{|c|}{ Body Weight } & \multirow{2}{*}{$\begin{array}{l}\text { Period } \\
\text { of } \\
\text { Injec- } \\
\text { tions } \\
\text { (days) }\end{array}$} & \multicolumn{2}{|c|}{ Ataxia } & \multicolumn{3}{|c|}{ Disappearance of } \\
\hline & & $\begin{array}{l}\text { Begin- } \\
\text { ning } \\
(\mathrm{kg})\end{array}$ & $\begin{array}{l}\text { End } \\
(\mathrm{kg})\end{array}$ & & $\begin{array}{c}\text { Day of } \\
\text { Appearance }\end{array}$ & $\begin{array}{l}\text { Degree of } \\
\text { Symptom }\end{array}$ & $\begin{array}{c}\text { Righten- } \\
\text { ing } \\
\text { Reflex } \\
\end{array}$ & $\begin{array}{c}\text { Horizontal } \\
\text { Nystag- } \\
\text { mus }\end{array}$ & $\begin{array}{c}\text { Preyer's } \\
\text { Reflex }\end{array}$ \\
\hline 1002 & 150 & 2.7 & 2.4 & 87 & 29 & + & + & + & + \\
\hline 1001 & 200 & 2.05 & 1.5 & 44 & 22 & + & + & + & + \\
\hline 1009 & 300 & 2.4 & 2.0 & 29 & 11 & $H$ & + & + & + \\
\hline
\end{tabular}

Ataxia appeared in one cat 29 days after injection of $150 \mathrm{mg} / \mathrm{kg}$, and in the second cat 22 days after injection of $200 \mathrm{mg} / \mathrm{kg}$, and in the third cat 11 days after injection of $300 \mathrm{mg} / \mathrm{kg}$. Nystagmus, rightening reflex and Preyer's reflex disappeared. Their disappearance occured sooner in direct proportion to the higher dcsage of the drug.

2) According to Molitor(1), it has been elucidated that if streptomycin was injected intracisternally or intrathecally in rabbits, such disturbances of the eighth nerve which occured with intramuscular injections would not be induced. Therefore we experimented whether these facts were caused by injecting streptomycin and dihydrostreptomycin intracisternally in cats.

We injected intracisternally streptomycin sulfate $0.5 \sim 3.0 \mathrm{mg} / \mathrm{kg}, 3.0 \sim 5.0$

Table 2

Streptomycin Sulfate and Dihydrostreptomycin Sulfate Injected Intracisternally

\begin{tabular}{|c|c|c|c|c|c|c|c|c|c|}
\hline \multirow{2}{*}{$\begin{array}{l}\text { Cat } \\
\text { No. }\end{array}$} & \multirow{2}{*}{$\begin{array}{c}\text { Dose } \\
(\mathrm{mg} / \mathrm{kg})\end{array}$} & \multicolumn{2}{|c|}{ Body Weight } & \multirow{2}{*}{$\begin{array}{l}\text { Period } \\
\text { of } \\
\text { Injec- } \\
\text { tions } \\
\text { (days) }\end{array}$} & \multicolumn{2}{|c|}{ Ataxia } & \multicolumn{3}{|c|}{ Disappearance of } \\
\hline & & $\begin{array}{l}\text { Begin- } \\
\text { ning } \\
(\mathrm{kg})\end{array}$ & $\begin{array}{l}\text { End } \\
(\mathrm{kg})\end{array}$ & & Day of & $\begin{array}{l}\text { Degree of } \\
\text { Symptom }\end{array}$ & $\begin{array}{l}\text { Righten- } \\
\text { ing } \\
\text { Reflex }\end{array}$ & $\begin{array}{c}\text { Horizontal } \\
\text { Nystag- } \\
\text { mus }\end{array}$ & $\begin{array}{c}\text { Preyer's } \\
\text { Reflex }\end{array}$ \\
\hline
\end{tabular}

\begin{tabular}{c|c|c|c|c|c|c|c|c|c}
\hline 2004 & $0.5 \sim 3.0$ & 3.5 & 2.9 & 22 & 14 & + & + & - & + \\
\hline 2006 & $3.0 \sim 5.0$ & 2.8 & 2.0 & 25 & 18 & + & + & $+(1)$ & + \\
\hline 2015 & 5.0 & 3.2 & 2.4 & 17 & 10 & + & + & $+(2)$ & + \\
\hline
\end{tabular}

Dihydrosteptomycin sulfate

\begin{tabular}{c|c|c|c|c|c|c|c|c|c}
\hline \hline 2016 & 5.0 & 2.9 & 2.8 & 21 & 21 & \pm & + & - & + \\
\hline 2021 & 5.0 & 3.7 & 3.1 & 23 & 22 & \pm & + & - & + \\
\hline
\end{tabular}

(1) It disappeared in 21 days after Stopping the injections.

(2) It disappeared in 28 days after Stopping the injections. 
$\mathrm{mg} / \mathrm{kg}, 5.0 \mathrm{mg} / \mathrm{kg}$ every day for $22,25,17$ days respectively in three cats. Ataxia appeared in all cats in 14,18, 10 days respectively after injection. The rightening reflex and Preyer's reflex disappeared the same as in those cats which received intramuscular injections. However, the signs of horizontal nystagmus as shown in Table 2 are quite different from those shown in Table 1 , in the case of cat No. 2004, the horizontal nystagmus did not disappear, and in the case of the other two cats, it disappeared 21 and 28 days after stopping the injections. (See Table 2).

Next we injected intracisternally, dihydrostreptomycin sulfate $5.0 \mathrm{mg} / \mathrm{kg}$ every day for 21 days and 23 days respectively in two cats. In these cats, ataxia appeared in 21 days and 22 days respectively after the injections, the rightening refiex and Preyer's reflex disappeared, but nystagmus did not.

Immediately after the intracisternal injection of streptomycin sulfate the following symptoms appeared. First the cats were very excited, then there appeared muscular shivering followed by spontaneous nystagmus, convulsive scratching of the back of the ear helix by the hind leg, dilation of the blood vessels of the ear helix, nausea and vomiting. These symptoms disappeared within twelve hours. The nausea and vomiting was so severe that all cats lost weight on completion of the experiments.

The symptoms after the intracisternal injection of streptomycin sulfate appeared as follows. First ataxia affected the walking, i.e. shuffling of hind legs, especially the left leg (we call this + ). It appears in 10 18 days (average 14 days) after the beginning of the injections. When ataxia progresses so rapidly the cats walk in a shuffling manner with both hind legs. When they try to walk, they can only push their forelegs forward, but they can not raise their

Table 3

Distrycin Injected Intracisternally and Intramuscularly

\begin{tabular}{|c|c|c|c|c|c|c|c|c|c|c|}
\hline \multirow{2}{*}{$\begin{array}{l}\text { Cat } \\
\text { No. }\end{array}$} & \multirow{2}{*}{$\begin{array}{c}\text { Dose } \\
\text { (mg/ } \\
\mathrm{kg} \text { ) }\end{array}$} & \multirow{2}{*}{$\begin{array}{l}\text { Period } \\
\text { of } \\
\text { Injec- } \\
\text { tions } \\
\text { (day) }\end{array}$} & \multicolumn{2}{|c|}{ Body Weight } & \multirow{2}{*}{$\begin{array}{l}\text { Gen- } \\
\text { eral } \\
\text { Con- } \\
\text { dition }\end{array}$} & \multicolumn{2}{|c|}{ Ataxia } & \multicolumn{3}{|c|}{ Disappearance of } \\
\hline & & & $\begin{array}{c}\text { Begin- } \\
\text { ning } \\
(\mathrm{kg})\end{array}$ & $\begin{array}{r}\text { End } \\
(\mathrm{kg})\end{array}$ & & $\begin{array}{l}\text { Day of } \\
\text { Appear- } \\
\text { ance }\end{array}$ & $\begin{array}{l}\text { Degree of } \\
\text { Symptom }\end{array}$ & $\begin{array}{l}\text { Righten- } \\
\text { ing } \\
\text { Reflex }\end{array}$ & $\begin{array}{c}\text { Horizontal } \\
\text { Nystag- } \\
\text { mus }\end{array}$ & $\begin{array}{c}\text { Preyer's } \\
\text { Reflex }\end{array}$ \\
\hline
\end{tabular}

Intracisternal Injection

\begin{tabular}{c|c|c|c|c|c|c|c|c|c|c|}
\hline \hline 1007 & 5.0 & 16 & 2.8 & 2.6 & + & 12 & H & + & + & + \\
\hline 2013 & 5.0 & 17 & 2.9 & 2.2 & + & 10 & H & ++ & + & + \\
\hline 2017 & 5.0 & 12 & 3.4 & 2.4 & W & 7 & + & + & + & + \\
\hline
\end{tabular}

Intramuscular Injection

\begin{tabular}{l|l|l|l|l|l|l|l|l|l|l|}
\hline \hline 1020 & 330 & 24 & 2.4 & 1.8 & \pm & 18 & + & + & + & \pm \\
\hline
\end{tabular}


hunch and they tumble in a sideways manner and can not walk normally (we call

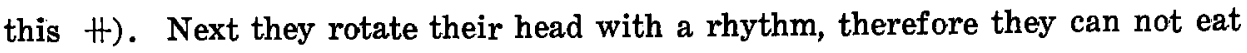
properly ( we call this $\mathrm{H}$ ).

3) Hinshow (3) has tried to decrease the side effects of streptomycin by giving distrycin which is a mixture of streptomycin and dihydrostreptomycin. We also injected this drug intramuscularly and intracisternally, and we observed its neurotoxicity. Distrycin was given $330 \mathrm{mg} / \mathrm{kg}$ intramuscularly daily for 24 days and $5 \mathrm{mg} / \mathrm{kg}$ intracisternally daily for $12 \sim 17$ days.

In the cases of intracisternal injection of distrycin, the symptoms appeared more seriously than in those with streptomycin and dihydrostreptomycin. For example, ataxia appears on the average of 10 days after injections. The general condition of the animals is more serious and the decrease of the body weight is more marked.

4) Next, we used streptidine hydrochloride that was separated from streptomycin sulfate at the Keio Pharmaceutic Institute. The dosage of streptidine was $2 \mathrm{mg} / \mathrm{kg}$ (in rare cases, $2.5 \sim 5.0 \mathrm{mg} / \mathrm{kg}$ ) (See Table 4).

Table 4

Streptidine Hydrochloride and Guanidine Carbonate Injected Intracisternally

\begin{tabular}{|c|c|c|c|c|c|c|c|c|c|c|}
\hline \multirow{2}{*}{$\begin{array}{l}\text { Cat } \\
\text { No. }\end{array}$} & \multirow{2}{*}{$\begin{array}{c}\text { Dose } \\
(\mathrm{mg} / \\
\mathrm{kg})\end{array}$} & \multirow{2}{*}{$\begin{array}{c}\text { Period } \\
\text { of } \\
\text { Injec- } \\
\text { tions } \\
\text { (day) }\end{array}$} & \multicolumn{2}{|c|}{ Body Weight } & \multirow{2}{*}{$\begin{array}{c}\text { Gen- } \\
\text { eral } \\
\text { Con- } \\
\text { dition }\end{array}$} & \multicolumn{2}{|c|}{ Ataxia } & \multicolumn{3}{|c|}{ Disappearance of } \\
\hline & & & $\begin{array}{c}\text { Begin- } \\
\text { ning } \\
(\mathbf{k g})\end{array}$ & $\begin{array}{l}\text { End } \\
(\mathrm{kg})\end{array}$ & & $\begin{array}{l}\text { Day of } \\
\text { Appear- } \\
\text { ance }\end{array}$ & & $\begin{array}{l}\text { Righten- } \\
\text { ing } \\
\text { Reflex }\end{array}$ & $\begin{array}{c}\text { Horizontal } \\
\text { Nystag. } \\
\text { mus }\end{array}$ & $\begin{array}{l}\text { Pre } \\
\text { Re }\end{array}$ \\
\hline
\end{tabular}

Streptidine Hydrochloride

\begin{tabular}{c|c|c|c|c|c|c|c|c|c|c}
\hline \hline 2022 & 2.0 & 14 & 3.5 & 2.55 & H & 8 & + & + & - & + \\
\hline 2023 & 2.0 & 14 & 2.1 & 1.7 & + & 8 & + & + & - & + \\
\hline 2005 & $\begin{array}{r}2.5 \\
5.0\end{array}$ & 24 & 2.8 & 2.0 & + & 10 & + & + & + & + \\
\hline
\end{tabular}

Guanidine Carbonate

\begin{tabular}{c|c|c|c|c|c|c|c|c|c}
\hline \hline 2007 & 5.0 & 1 & 3.25 & & \multicolumn{4}{|c|}{ Immediate death } \\
\hline 2010 & 1.0 & 7 & 2.0 & 1.85 & \multicolumn{2}{|c|}{ Died on the 21st day of the beginning of the injection. } \\
\hline 2011 & 0.5 & 50 & 1.6 & 2.0 & - & - & & - & - \\
\hline
\end{tabular}

Ataxia in these cases appeared much sooner than with the other drugs. The rightening reflex and Preyer's reflex disappeared. The horizontal nystagmus did not sometimes disappear or sometimes disappear the same as with intracisternal injections of streptomycin.

5) Then, we studied the neurotoxic effects of the intracisternal injection of guanidine carbonate (Guanidine consists of two molecules of streptidine). 
As illustrated in Table 4, when guanidine carbonate $5.0 \mathrm{mg} / \mathrm{kg}$ was given intracisternally the cats died of strong tetanic convulsion immediately after the injection. Using $1 \mathrm{mg} / \mathrm{kg}$ of guanidine carbonate, relatively strong tetanic, or ticcramph occured, lasting for 30 minutes. They were unable to stand up and were exhausted. One cat died 21 days after the beginning of the injections.

Next, when guanidine $0.5 \mathrm{mg} / \mathrm{kg}$ was injected intracisternally every day, convulsions were weaker, exhibiting a form of jerky spasms for 5 minutes. No neurotoxic signs appeared in this dose even after three months.

6) The results of cochlear microphonic response. Cats were given intramuscularly $10 \% \quad 1.5 \mathrm{cc}$ hexobarbital before measurement of cochlear microphonic response for the purpose of narcosis. Streptomycin $5 \mathrm{mg} / \mathrm{kg}$ dihydrostreptomycin $5 \mathrm{mg} / \mathrm{kg}$ distrycin $5 \mathrm{mg} / \mathrm{kg}$ and streptidine $2 \mathrm{mg} / \mathrm{kg}$ were injected intracisternally every day. Cochlear microphonic responses were recorded at the round window after the appearance of neurotoxicity. Table 5 shows the values of cochlear maximum microphonic response obtained with the various drugs.

Table 5

Effect of Intracisternal Injection on Cochlear Microphonic Response

\begin{tabular}{|c|c|c|c|c|c|}
\hline$\underbrace{\text { Drugs }}_{\begin{array}{c}\text { Frequency } \\
* \text { c. p. s. }\end{array}}$ & Normal & $\begin{array}{c}\begin{array}{c}\text { Streptomycin } \\
\text { sulfate } \\
5 \mathrm{mg} / \mathrm{kg}\end{array} \\
\end{array}$ & $\begin{array}{c}\text { Dihydro- } \\
\text { streptomycin } \\
5 \mathrm{mg} / \mathrm{kg} \\
\end{array}$ & $\begin{array}{c}\text { Distrycin } \\
5 \mathrm{mg} / \mathrm{kg}\end{array}$ & $\begin{array}{c}\text { Streptidine } \\
5 \mathrm{mg} / \mathrm{kg}\end{array}$ \\
\hline $\begin{array}{c}500 \\
\text { c. p. s. }\end{array}$ & $\begin{array}{r}500 \sim 700 \\
\mu \mathrm{V}\end{array}$ & $\begin{array}{l}500 \\
\mu \mathrm{V}\end{array}$ & $\begin{array}{l}75 \\
\mu \mathrm{V}\end{array}$ & $\begin{array}{c}300 \\
\mu \mathrm{V}\end{array}$ & $\stackrel{220}{\mu \mathrm{V}}$ \\
\hline $\begin{array}{l}1000 \\
\text { c. p. s. }\end{array}$ & $\begin{array}{l}680 \\
\mu \mathrm{V}\end{array}$ & $\begin{array}{c}600 \\
\mu \mathrm{V}\end{array}$ & $\begin{array}{l}300 \\
\mu \mathrm{V}\end{array}$ & $\begin{array}{l}300 \\
\mu \mathrm{V}\end{array}$ & $\stackrel{500}{\mu \mathrm{V}}$ \\
\hline $\begin{array}{l}2000 \\
\text { c. p. s. }\end{array}$ & $\begin{array}{r}680 \sim 900 \\
\mu \mathrm{V}\end{array}$ & $\begin{array}{l}330 \\
\mu \mathrm{V}\end{array}$ & $\stackrel{220}{\mu \mathrm{V}}$ & $\begin{array}{r}440 \\
\mu \mathrm{V}\end{array}$ & $\stackrel{350}{\mu \mathrm{V}}$ \\
\hline $\begin{array}{c}4000 \\
\text { c. p. s. }\end{array}$ & $\begin{array}{l}500 \\
\mu \mathrm{V}\end{array}$ & $\begin{array}{l}50 \\
\mu \mathrm{V}\end{array}$ & $\begin{array}{l}17 \\
\mu \mathrm{V}\end{array}$ & $\begin{array}{l}220 \\
\mu \mathrm{V}\end{array}$ & ${ }_{\mu \mathrm{V}}^{160}$ \\
\hline
\end{tabular}

* c. p. s..... Cycle per Second.

The maximum microphonic response of $4 \mathrm{kc}$ in all the cats which received the test drugs was lower than normal. This phenomenon demonstrates the disturbance of high tone areas. It is very interesting that there is a marked disturbance of lower tone areas in the group of dihydrostreptomycin.

\section{DISCUSSION}

1) In most cases of intracisternal injection of streptomycin and its analogues in cats, horizontal nystagmus did not always disappear at the same time as in those with intramuscular injections, but it disappeared later than in those cats which had injections. We do not understand why it is caused, and we 
believed that these experimental results were different from Molitor's in rabbits. We were successful in inducing the similar neurotoxic effects using streptomycin and its analogues intracisternally as well as intramuscularly.

2) It is recognized by many researchers that vestibular disturbances are mostly caused by streptomycin and auditory disturbances are mostly caused by dihydrostreptomycin. The results of our experiments agree with this, even in most cases of intracisternal injection.

3) Streptidine can cause chronic toxicity like streptomycin when it is injected intracisternally. However, guanidine does not cause the neurotoxic disturbances, since we think, streptidine is a radical which accounts for the neurotoxic effects of both streptomycin and dihydrostreptomycin.

4) Contrary to Hinshows experiment, our experiment showed that distrycin is markedly more neurotoxic than streptomycin and dihydrostreptomycin in the intracisternal and intramuscular injection in cats.

We shall review next time whether the histological pictures of these cats were damaged more seriously than those of streptomycin cats.

\section{CONCLUSION}

1) Streptomycin, dihydrostreptomycin, distrycin and streptidine can be the cause of the chronic neurotoxicity in cats. However, guanidine can not be the cause of it.

2) Even in the intracisternally injection, streptomycin, dihydrostreptomycin, distrycin and streptidine can cause the similar neurotoxicity in cats as in those with intramuscular injection.

3) The neurotoxic effects of distrycin occured more quickly and are more serious than those of streptomycin and dihydrostreptomycin in cats.

\section{REFERENCES}

1. Molitor, H.: Streptomycin. The Williams \& Willkins Co. p. 254-275, 1949.

2. Hawkins, J. E.: The Ototoxicity of Streptomycin. Ann. Otol. Rhin. \& Larying. 16: 789-809, 1952.

3. Hinshow, H. C., Heck, W. E., Lynch, W. J., Graves, H. L., \& Thoren, M. E.: Reduced Ototoxicity by Combined Streptomycin Treatment of Tuberculosis. Stanford Med. Bull. 11: 234-236, 1953. 